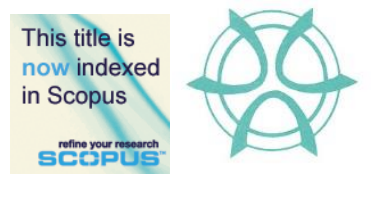

PLANNING MALAYSIA:

Journal of the Malaysian Institute of Planners

Volume XI (2013), Page 139 - 158

\title{
ANALYSIS OF FACTORS INFLUENCING USE OF MOTORCARS IN INTERNATIONAL ISLAMIC UNIVERSITY MALAYSIA
}

\author{
Nelza Lynna Abdul Rahim ${ }^{1}$ and Abdul Azeez Kadar Hamsa ${ }^{2}$ \\ ${ }^{1} \& 2$ Kulliyyah of Architecture and Environmental Design \\ INTERNATIONAL ISLAMIC UNIVERSITY MALAYSIA
}

\begin{abstract}
Trends in transport have been changing and will continue to change over the next few years. A number of issues on the national and international transport scene have driven a need for organisations such as the Universities to further develop a sustainable transport strategy to encourage use of sustainable transport modes to achieve better environmental qualities on-campus. This research highlights the factors influencing the choice of using motorcars among student population for trips on-campus. A self-administered questionnaire was designed to collect data on "trip-makers" and "trip-making" characteristics and "preference to use motorcars as their main travel mode choice". The questionnaires were distributed to the student population who use motorcars oncampus. The total sample size selected was 100 and samples were selected from each Mahallah (hostel) by using stratified sampling method. The factors influencing use of motorcars on-campus was analysed using Pearson ChiSquare, Pearson's Product-Moment Correlation Coefficient and t-test. The preference of the respondents on the measures that should be implemented to attract students to travel by sustainable transport modes such as walking, cycling, carpooling, or using public transportation are also discussed. The factors such as "year of study", "vehicle registration status", "travel time by walking from Mahallah (hostel) to Kulliyyah (faculty)" and "experienced delay time to the Kulliyyah" were found to influence the use of motorcars on-campus. $86 \%$ of the respondents were willing to shift from using motorcars to sustainable transportation modes. Recommendations to realize the willingness to shift from motorcars to other travel modes include: formulation of policy by the University authority to reduce the over-dependence on motorcars oncampus; provision and management of efficient and effective public transportation services on-campus; provision and improvement of infrastructure
\end{abstract}

${ }^{1}$ Undergraduate Student, Department of Urban and Regional Planning. Email: nelzalyna@ @otmail.com

${ }^{2}$ Associate Professor, Department of Urban and Regional Planning. Email: azeez@iium.edu.my 
Nelza Lynna Abdul Rahim \& Abdul Azeez Kadar Hamsa

Analysis of Factors Influencing Use of Motorcars in International Islamic University Malaysia

to facilitate walking and cycling on-campus and strict enforcement on the use of illegal motorcars on-campus.

Keywords: motorcar, travel mode, travel behaviour, sustainable transport, University campus.

\section{INTRODUCTION}

The car is popular among commuters because it generally provides high levels of mobility and convenience. As many studies had shown, car ownership and its use have risen rapidly with increased income. The increasing affordability of cars is the most important explanation for the worldwide growth in motorisation in recent decades (Ingram and Liu, 1999, Schafer and Victor, 2000, Downs, 2004). Cars, being one of the means of transport, have significant impact and ability to affect the quality of environment in a place, as in most cases, transport is the main source of pollution (World Bank, 1996).

According to Norsyuhadah Norzalwi and Amiruddin Ismail (2011), University campuses can be defined as a small "city" because they commonly have their own communities, typical daily activities such as working, studying, businesses and own independent infrastructure facilities. However, they also experiencing the same problems as major cities are experiencing such as increase in the use of private transport, traffic congestions, noise pollutions, and also environmental problems. The motorization trends in University campuses are also similar with that of cities in terms of high use of private cars (Norsyuhadah Norzalwi and Amiruddin Ismail, 2011). Therefore, a sustainable transportation planning is in great need for University campuses to encourage the use of non-motorized travel modes, public transportation and other sustainable transportation modes in campuses.

This research discusses on the analysis of factors affecting use of motorcars as travel mode choice among on-campus University students. Because of the growing number of motorcars on-campus especially by student community, it is imperative to ascertain the likely reasons for the use of motorcars on campus. On-campus student population who own motorcars and travel to Kulliyyah (faculty) from Mahallah (hostel) by their motorcars either regularly or occasionally for attending classes was targeted. Regular users of the motorcars are the individuals who use motorcars all the time of their trips oncampus and occasional users are those who use motorcars only during some time of their trips. 
PLANNING MALAYSIA:

Journal of the Malaysia Institute of Planners (2013)

\section{LITERATURE REVIEW ON FACTORS INFLUENCING MOTORCARS AS TRAVEL MODE CHOICE}

According to Hjorthol (1999) and Forward (1998b), there are several reasons why motorcars are so popular. It is mentioned that the use of motorcar provides a convenient and comfortable way to travel. The driver and passengers can travel undisturbed and feel secure, and a car journey is more time-saving. In addition, the motorcars also have cultural and symbolic values. Jensen (1997) arrives at the conclusion that the motorcar is not only a convenient mode of transport but also satisfies other needs, for example feeling that one is in control of one's journey.

Normal transport-economic models assume that people are rational beings and choose the mode of travel that gives the most benefit. Many researchers, however, had considered that people choose their mode of transport according to their feelings and habits. This manifests itself, in fact, that people do not change their behaviours just because conditions change, for example, improved public transport, since people weigh in more values on feelings and personal habits than time and cost when they choose their mode of transport (Goodwin, 1998 and Ben-Akiva et.al., 1999).

Meanwhile, Goodwin (1991) also mentioned that the motorcar is an important part of people's lives from an early age. Even when they are very young, children learn that the motorcar is a status symbol. It is also considered that taking one's driving licence as an important ritual in their early age. The motorcar is spotlighted in the films and made to symbolise freedom and strength. The car is implemented early in children's lives and becomes part of their everyday life together with feed bottles, comforters, and mom and dad. This is why methods of persuasion and other measures in the form of incentives and threats have largely proved ineffectual other than in just a few per cent of cases (Goodwin, 1991).

According to Lindström Olsson (2003), the choice of travel mode is affected by many factors, everything from transport-specific factors (describing the various components of the transport system) to individual-related factors such as a person's attitudes and habits. The choice of travel mode are influenced by the factors such as speed, journey length, comfort, convenience, cost, reliability of alternative modes, the availability of specific travel modes, town size, age, and composition; and the socio-economic status of the persons making the journeys. These factors are classified in many different ways in the literatures (Lindström Olsson, 2003). The measures of competitiveness between 
Nelza Lynna Abdul Rahim \& Abdul Azeez Kadar Hamsa

Analysis of Factors Influencing Use of Motorcars in International Islamic University Malaysia

different travel modes are usually derived from an analysis of three sets of factors:

a) Characteristics of the journey to be made (length, time of the day the journey is made, purpose of the journey, etc.)

b) Characteristics of the persons making the journey (car ownership, income, social standing, gender, age, etc.)

c) Characteristics of the transportation system (travel time involved, cost, accessibility, comfort, etc.)

Many studies showed that the travel time and cost are crucial to the choice of travel mode and the decision to travel (Algers et al., 1995). Kottenhoff (1999) showed that the level of comfort and services provided by travel modes are also very important. A study in Gothenburg on motorists' choice of trackbound taxis as a hypothetical travel mode, the car drivers had indicated that the following factors were important: low fare, maximum 300m walking distance, substantial time gain, enjoyable, comfortable, clean, tidy and hygienic. Motorists want short distances to public transport, up to 3 minutes, as compared to public transport passengers who can accept up to 10 minutes walking distance (Loncar-Lucassi, 1998).

In an attempt to encourage the use of alternative mode of transport other than motorcars, the University of Bradford applies travel plan to its community in order to reduce not only the amount of traffic but also to promote a wide range of more environment friendly and healthy transport options (University of Bradford Smart Move Travel Plan, 2004-2009). Some of the initiatives that are introduced as part of travel plan at the University of Bradford include: measures to encourage flexible work practices, walking, cycling, greater use of public transport, car sharing and car parking management (University of Bradford Smart Move Travel Plan, 2004-2009).

The University of Manchester in UK has recognized the need to ensure the use of sustainable mode of transportation by the University's population. The University has developed the first Green travel plan initiatives to support its commitment on the use of sustainable transportation modes to address the growing transport and car parking issues (University of Manchester Green Travel Plan, 2006-2011). Some of the significant components in the University's Green travel plan include: additional facilities for cyclist and pedestrians; introduction of new parking charges to encourage car sharing; further development of the discounted public transport ticketing scheme; producing a student travel plan; and working with city council to integrate the 
newly formed cycling routes as part of the public realm into the wider city cycle network (University of Manchester Green Travel Plan, 2006-2011).

\section{BACKGROUND OF STUDY AREA}

This study was carried out in IIUM Main Campus that is nestled in a valley in the district of Gombak in the state of Selangor. IIUM was selected because of the growing number of motorcar use among the student population. The number of registered cars on-campus has been increasing at $1.8 \%$ annually from 2007 to 2010 (Farah Diyanah Ismail et.al. 2012). Additionally, the increase in the use of motorcars by students has been inducing tremendous pressure on the limited road and related infrastructure especially parking both at the Kulliyyahs and Mahallahs The parking spaces at the Kulliyyahs were highly utilized at an average of $83.55 \%$ indicating high parking demand (Farah Diyanah Ismail et.al. 2012).

IIUM is located approximately 10 kilometres at the north-east direction from Kuala Lumpur at the foot of the Gombak Hillside.The campus is also greatly accessible via Middle Ring Road 2 (MRR2), Karak Highway or via Gombak Road. The University was established on $23^{\text {rd }}$ May 1983. This Garden of Knowledge and Virtue campus covers approximately 700 acres of land area accommodating 17 hostels for students housing or known as Mahallah and 8 faculties or known as Kulliyyah. At present, the University accommodates 2,708 employees (IIUM Management Services Division, 2011) and 15,068 students (IIUM, Security Management Unit, 2012). The campus is also provided with 8,618 parking spaces (IIUM, Security Management Unit, 2012).

As of March 2012, there were 1,961 students registered with Security Management Unit for the legal use of motorcars on-campus. According to Security Management Unit, the number of vehicle registration applications among students in the 2011/2012 academic session has decreased by $6.41 \%$ from 2010/2011 academic session. It is obviously due to change in policy by the University management allowing only 3rd year students, 4th year students and above to apply for vehicle stickers for the use of motorcars on-campus. However, there was slight increase in the number of vehicle registration application, $0.78 \%$ from $2007 / 2008$ to $2008 / 2009$ academic session and $1.27 \%$ from $2008 / 2009$ to $2009 / 2010$ academic session.

The main buildings that include masjid, administration buildings and Kulliyyahs are placed at the central area and Mahallahs and other facilities for students are located surrounding the main buildings (Refer to Fig. 1). The 
Nelza Lynna Abdul Rahim \& Abdul Azeez Kadar Hamsa

Analysis of Factors Influencing Use of Motorcars in International Islamic University Malaysia

students of IIUM are free to choose any travel modes that they prefer to go to Kulliyyahs from their Mahallahs for attending classes. The available travel modes for the students within the campus are walking, cycling, public transportation and private vehicle. The campus also provides intra-campus bus services for the IIUM community. However, these services are limited and provided only to those students staying at the selected Mahallahs.

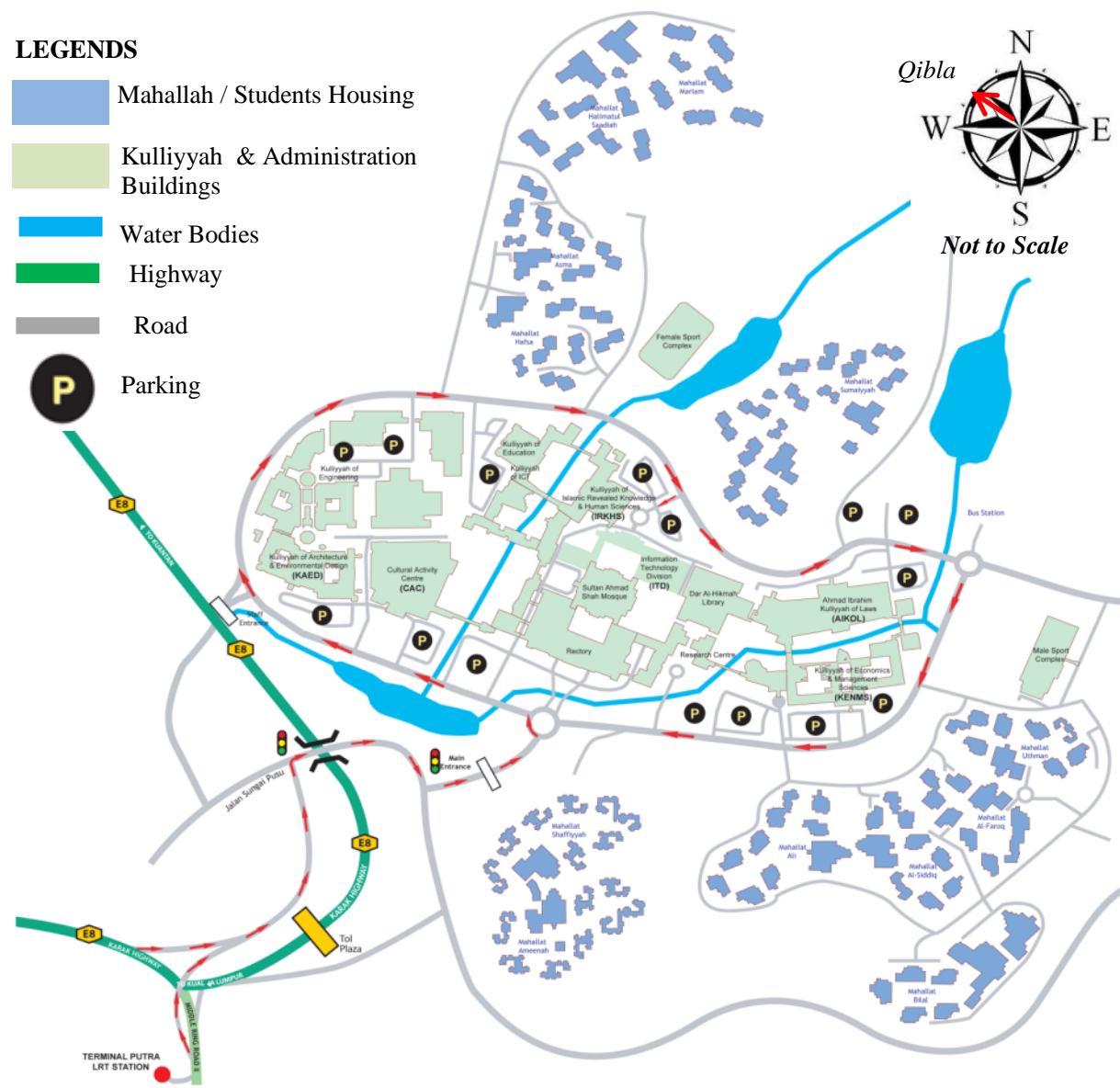

Figure 1: Main Campus of International Islamic University Malaysia Source: www.iium.edu.my. Retrieved March 23, 2012 


\section{RESEARCH APPROACH}

The data for this study was collected by using two data sources, which are primary data and secondary data. The primary data collection methods include self-administered questionnaire survey, observational survey, and structured interview. The secondary data was collected mainly from the related agencies and through other literary sources. The primary and secondary data were then analysed by using analysis methods which include univariate analysis, Relative Importance Index (RII), bivariate and $t$-test analysis.

\section{Data collection}

A self-administered questionnaire was designed to collect data on "trip-makers" and "trip-making" characteristics and "preference to use motorcars as their main travel mode choice" on-campus. Data on motorcar users' willingness to travel by sustainable transportation modes such as walking, bicycling and public transport were also collected. Both Revealed-Preference (RP) and Stated Preference (SP) approach were applied to collect data on trips which were made and trips which will be made by using sustainable transportation modes.

A self-administered questionnaire survey was conducted targeting 100 on-campus students having immediate access to their motorcars for use oncampus either regularly or occasionally. The targeted population was divided into subpopulations or strata according to Mahallahs (hostel) for the selection of samples. Upon dividing the population into subpopulation, samples were selected from each subpopulation by using stratified random sampling procedures. The sample size from each stratum was selected by using proportional allocation approach. MugoFridah W. (2002) mentioned that, in stratified sampling, a population can be divided into different groups which may be based on some characteristics or variables, and in this research, the population was subdivided according to Mahallahs before selecting samples from each Mahallah. Table 1 shows the proportional allocation of samples by Mahallah.

The questionnaire includes three main parts namely "trip-makers characteristics", "trip-making characteristics" and "preference of motorcars as travel mode choice". The frequency of using motorcars, reasons for using motorcars, willingness to shift from using motorcars to walking, cycling and public transport and preferences on the application of measures which encourages to use sustainable mode of transportation are some of the questions asked under the "preference of motorcars as travel mode choice" section. 
Nelza Lynna Abdul Rahim \& Abdul Azeez Kadar Hamsa

Analysis of Factors Influencing Use of Motorcars in International Islamic University Malaysia

The students were asked about their willingness to shift from using motorcars to sustainable travel modes and also their preferences on measures that should be taken to induce shift from motorcars to other transportation modes. The preferences of the students on the use of various sustainable transportation modes other than motorcars were measured by using the Likert Scale. The scale used ranges from the "most preferred" to the "least preferred" for the purpose of identifying the measures to allow shift from using motorcars to sustainable travel modes in the future. The other applications of Likert-Scale technique which were used in this study include perceptions of the students on the level of agreement on the use of motorcars on-campus (Colburn, 2003).

Table 1: Proportional Allocation of Samples by Mahallahs

\begin{tabular}{|l|c|c|}
\hline Mahallah & Number of Students & $\begin{array}{l}\text { Proportional } \\
\text { Allocation }\end{array}$ \\
\hline Al-Faruq & 732 & 5 \\
\hline Ali & 933 & 7 \\
\hline Ameenah & 995 & 7 \\
\hline As-Siddiq & 818 & 6 \\
\hline Asiah & 1087 & 8 \\
\hline Asma' & 764 & 5 \\
\hline Bilal & 941 & 7 \\
\hline Hafsa & 763 & 6 \\
\hline Halimatus Saa'diah & 707 & 5 \\
\hline Nusaibah & 780 & 5 \\
\hline Ruqayyah & 856 & 6 \\
\hline Safiyyah & 1203 & 8 \\
\hline Salahuddin Al-Ayyubi & 941 & 5 \\
\hline Sumayyah & 764 & 5 \\
\hline Uthman & 783 & 8 \\
\hline Zubair Awwam & 1015 & $\mathbf{1 0 0}$ \\
\hline Total & $\mathbf{1 4 , 1 9 4}$ & 7 Carce Student Affairs and Development Division of IIUM, 2012 \& Primary Calculan, 2012 \\
\hline
\end{tabular}

\section{Data analysis}

This research conducts its analysis in several phases. According to Herman Adèr (2008), data analysis is a process, within which several phases can be distinguished. The phases include data cleaning, initial data analysis and main data analysis. The structure for data analysis which was applied in this research is shown in Figure 2. 
Data cleaning was carried out during the data entry stage. It is a procedure in which data were closely inspected and incorrect data were corrected. The guiding principles, as provided by Adèr (2008) are that during subsequent manipulations of the data, it should always be possible to undo any data set alterations. All information and all alterations to the data set were carefully and clearly documented. For this research, the data cleaning and data entry was carried out using SPSS.

The initial data analysis describes the collected data in an organized and summarized form. In the main analysis phase, the method of analysis was applied in aiming to answer the research questions. In this research, the methods of analysis which were applied include univariate analysis, bivariate analysis and independent $t$-test.

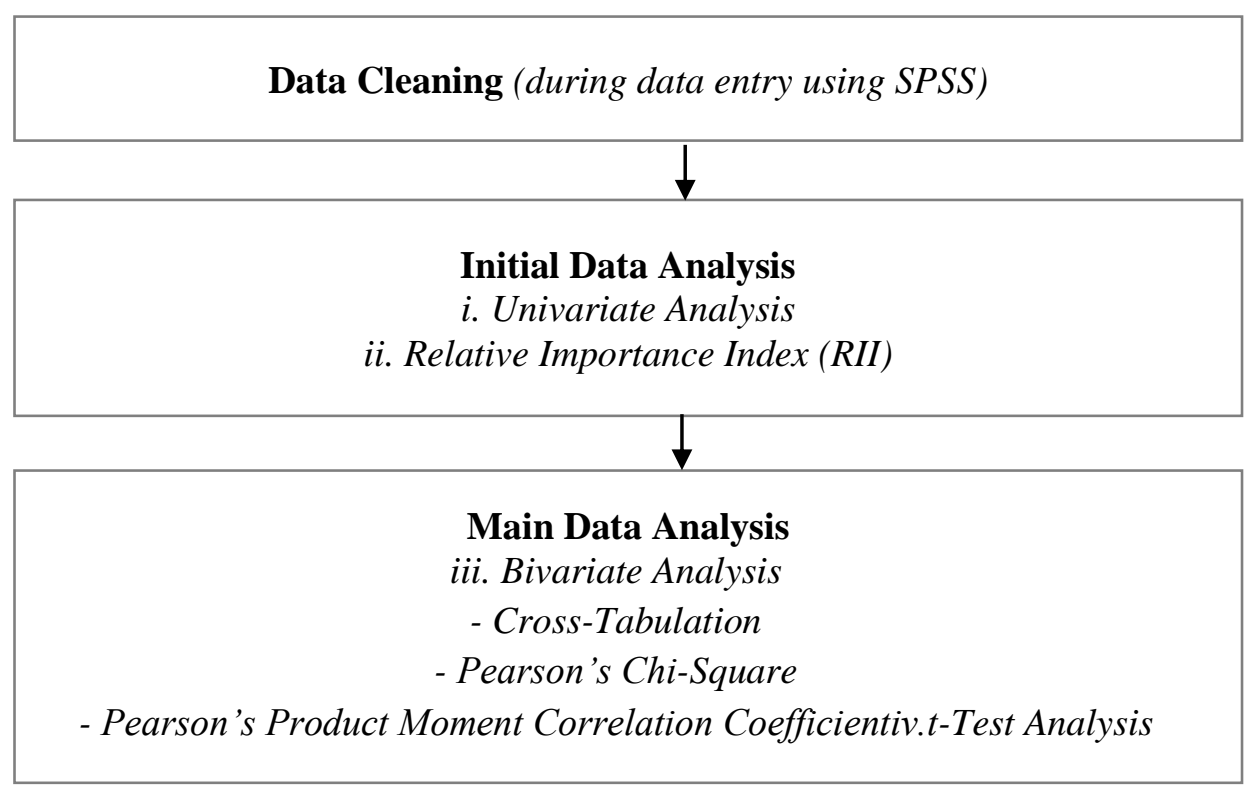

Figure 2: Structure of Data Analysis

Source: Herman Adèr, 2008 \& Primary Survey, 2012

\section{ANALYSIS AND FINDINGS}

The findings of this research are mainly help to answer research questions and to achieve the goal and objectives of the research. The analyses that were applied in this research include describing single variable, relationships or associations between variables, and finding differences between two groups 
Nelza Lynna Abdul Rahim \& Abdul Azeez Kadar Hamsa

Analysis of Factors Influencing Use of Motorcars in International Islamic University Malaysia

within a sample. The summary of the data analysis which was applied in this research includes:

- Initial data analysis, describing single variable by using univariate analysis and identifying ranking of the variables using Relative Importance Index (RII)

- Main data analysis, describing relationships between two variables by using cross-tabulation, finding associations between variables using Pearson's Chi-Square and Product-Moment Correlation Coefficient and finding differences between two groups in a sample using Independent t-Test

\section{Characteristics of the trip-makers}

The sample consists of $55 \%$ female students and $45 \%$ male students. $27 \%$ of the students were in the $2^{\text {nd }}$ year and $1^{\text {st }}$ year whereas $63 \%$ were in the $3^{\text {rd }}$ year and above. $96 \%$ of the total samples were studying bachelor degree programmes and only $4 \%$ were in the postgraduate programmes. The average age of the respondents is 23 years. The source of funding to support the students' degree programmes was found to be mainly from the government scholarship.

\section{Characteristics of trip-making}

About $75 \%$ of the samples have registered their vehicles with the IIUM security office. Most of the vehicles (68\%) driven on-campus was single occupancy (only the driver). The average delay time being experienced during their trips by motorcars from the Mahallah to the Kulliyyah was 10 minutes (one-way). The choices of travel modes (other than motorcar) available to the students as expressed by the respondents include: $100 \%$ walking, $38 \%$ public transportation, $19 \%$ bicycles and $7 \%$ motorcycles. The frequency of using travel modes other than motorcars was generally low among the respondents.

\section{Relationship between trip-makers and frequency of using motorcars on- campus}

The analysis of data using Chi-Square and Person Product Moment Correlation Coefficient has showed that, among the characteristics of trip-makers (gender, source of finance, and year of study), the relationship between "year of study" and "frequency of using motorcars on-campus" was statistically significant both at $95 \%$ and $99 \%$ confidence interval [Chi-Square value $=13.868 ; p=0.008$ ] However, the Cramer's V on this relationship only indicates a value of 0.372 , a moderate strength of association between these variables. Surprisingly, it was 
found that the $1^{\text {st }}$ and $2^{\text {nd }}$ year students were highly dependent on using motorcars for performing activities on-campus regularly. Though $1^{\text {st }}$ and $2^{\text {nd }}$ year students are not allowed to use motorcars on-campus, it can be noted that lack of enforcement, setting precedence by the previous batch students, lack of pedestrian, bicycle and public transport infrastructure are the likely reasons for this trend. This study includes $1^{\text {st }}$ and $2^{\text {nd }}$ year students as samples because of the growing number of these students using motorcars on-campus. Therefore, it can be concluded that "year of study" factor does influences use of motorcars on-campus. The students from lower level of study were highly dependent on motorcars than students from higher level of study.

\section{Relationship between trip-making and frequency of using motorcars on- campus}

This study showed that the vehicle registration status, travel time by walking to Kulliyyah from Mahallah and delay time to Kulliyyah from Mahallah were statistically related with frequency of using motorcars to the Kulliyyah either regularly or occasionally. The chi-square test on the relationship between "vehicle registration status" and "frequency of using motorcars to Kulliyyah" showed a Chi-Square value $=3.745 ; p=0.05$. Nearly $33 \%$ of the regular motorcar users and $16 \%$ of the occasional users were not registered their vehicles with the IIUM Security Unit to use their vehicles legally on-campus.

The Pearson Product-Moment Correlation on the relationship between "delay time to Kulliyyah" and "frequency of using motorcars" was found to be statistically related $[r(98)=-0.198, p=0.048]$. However, the relationship between these variables showed a negative correlation, which indicates as the delay time to the Kulliyyah increases, frequency of using motorcars decreases. Nearly $45 \%$ of the respondents who were regular motorcar users to the Kulliyyah were experienced a delay time of 10 to 15 minutes. Nearly $26 \%$ of the respondents who were regular motorcar users were experienced no delay during their trips to the Kulliyyah. About $26 \%$ of the respondents were experienced a delay time of less than 10 minutes when searching for a parking space near their Kulliyyahs. Only 3.3\% of the respondents who are regular motorcar users were experienced a delay time of 15 to 20 minutes. 
Nelza Lynna Abdul Rahim \& Abdul Azeez Kadar Hamsa

Analysis of Factors Influencing Use of Motorcars in International Islamic University Malaysia

Table 2 Results of the relationship between variables

\begin{tabular}{|l|c|c|c|c|l|}
\hline Variables & $\begin{array}{l}\text { Sample } \\
\text { size (n) }\end{array}$ & $\begin{array}{l}\text { Chi- } \\
\text { square }\end{array}$ & $\begin{array}{l}\text { Pearson } \\
\text { correlation } \\
\text { coefficient }\end{array}$ & $\begin{array}{l}\text { Significance } \\
\text { level (p) }\end{array}$ & Remarks \\
\hline $\begin{array}{l}\text { Vehicle } \\
\text { registration } \\
\begin{array}{l}\text { VS Frequency } \\
\text { of using } \\
\text { motorcars }\end{array}\end{array} \quad 100$ & 3.745 & - & 0.050 & $\begin{array}{l}\text { Statistically } \\
\text { Significant }\end{array}$ \\
\hline $\begin{array}{l}\text { Delay time to } \\
\text { Kulliyyah VS } \\
\text { frequency of } \\
\text { using } \\
\text { motorcars }\end{array}$ & 100 & - & -0.198 & 0.048 & $\begin{array}{l}\text { Statistically } \\
\text { Significant }\end{array}$ \\
\hline $\begin{array}{l}\text { Travel time by } \\
\text { walking VS } \\
\text { frequency of } \\
\text { using } \\
\text { motorcars }\end{array}$ & 100 & - & 0.433 & 0.000 & $\begin{array}{l}\text { Statistically } \\
\text { Significant }\end{array}$ \\
\hline
\end{tabular}

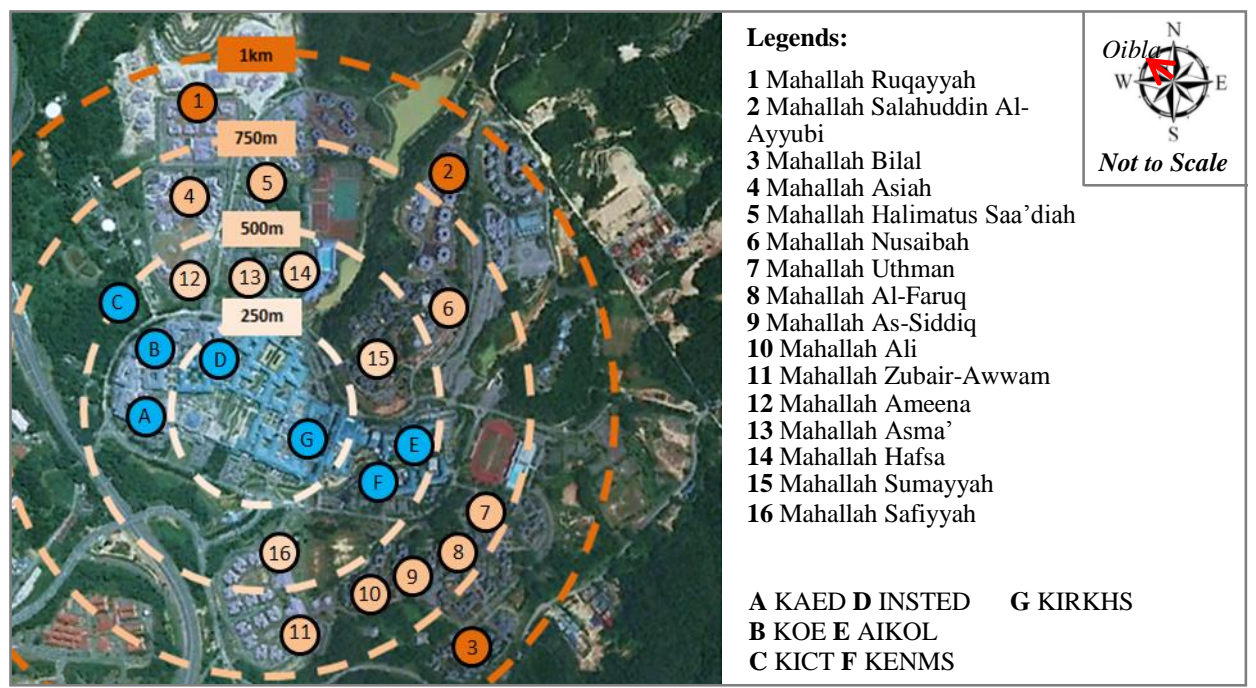

Figure 3: Distance between Origin (indicated in map by numbers) and Destination (indicated in map by alphabets)

Source: Google Earth \& Primary Survey, 2012

Note: KAED - Kulliyyah of Architecture and Environmental Design; KIRKHS - Kulliyyah of Islamic Revealed Knowledge and Human Science; KOE - Kulliyyah of Engineering; AIKOL - Ahmad Ibrahim Kulliyyah of Laws; KICT - Kulliyyah of Information and Communication Technology; KENMS Kulliyyah of Economic and Management Sciences; Kulliyyah - Faculty; Mahallah - Hoste 
Not surprisingly, the relationship between "travel time to Kulliyyah by walking" and "frequency of using motorcars to Kulliyyah" showed a positive correlation $[r(98)=0.433, p=0.000]$. It showed that as travel time by walking to the Kulliyyah increases, the frequency of using motorcars to Kulliyyah also increases. Nearly $85 \%$ of the occasional motorcar users were experienced travel time by walking between 5 and 10 minutes, while, $15.4 \%$ of the respondents who use cars occasionally to Kulliyyah were experienced travel time by walking to the Kulliyah between 10 and 15 minutes. Figure 3 shows the covering distances from the Mahallahs to the Kulliyyahs. Table 2 shows the summary of the results of the relationship between trip-making characteristics and frequency of using motorcars on-campus.

\section{Factors influencing use of motorcars on-campus}

The findings showed that $61 \%$ of the respondents were relying on motorcars regularly to go to Kulliyyah from Mahallah. Only 39\% of respondents were not fully dependent on motorcars to go to Kulliyyah from their Mahallahs because at times they depend on other available travel modes. Using motorcars regularly is defined as respondents being fully dependent on motorcar to go to Kulliyyah from their Mahallah at all time; and occasional use of motorcars to Kulliyyah is defined as respondents are not fully dependent on motorcars at all time and they keep their travel mode choice options open.

Of the 39 respondents who were using motorcars occasionally, about $44 \%$ of them agreed that they would use motorcars when the day is not busy and when there is plenty of available parking spaces on-campus especially near to their Kulliyyahs. The number of classes that the students need to attend in a day also influences the occasional use of motorcars. It was found that, $33.3 \%$ of the 39 respondents would use motorcars when they have more than one class in a day, and $38.5 \%$ of the 39 respondents would use motorcars when they have only one class in a day. The remaining $28.2 \%$ of them were not influenced at all on the frequency of "attending number of classes" in a day.

The level of agreement on the statement of factors influencing the use of motorcars by the respondents was analysed to determine the most likely influencing factors and the least likely influencing factors in using motorcars. The Relative Importance Index (RII) method was applied to rank the factors contributing towards the use of motorcars. Table 3 shows the ranking of each factor.

Expectedly, the "comfortable use of motorcars" to perform activities on-campus was ranked as the most important contributing factor for the use of 
Nelza Lynna Abdul Rahim \& Abdul Azeez Kadar Hamsa

Analysis of Factors Influencing Use of Motorcars in International Islamic University Malaysia

motorcars followed by "convenience" and "travel cost". The availability of parking spaces at the Kulliyyah, safety of motorcars parked at the Kulliyyah and Mahallah were ranked as the least important contributing factors towards the use of motorcars as expressed by the respondents.

Table 3: Factors Influencing the Use of Motorcars On-Campus $(\mathrm{n}=100)$

\begin{tabular}{|l|c|c|c|c|c|c|c|}
\hline \multirow{2}{*}{$\begin{array}{l}\text { Statements of } \\
\text { Factors }\end{array}$} & \multicolumn{5}{|c|}{ Frequency of Respondents } & \multirow{2}{*}{ RII** } & Rank \\
\cline { 2 - 8 } More Comfortable & 0 & 0 & 0 & 21 & 79 & 0.958 & 1 \\
\hline More Convenient & 0 & 0 & 0 & 30 & 70 & 0.940 & 2 \\
\hline $\begin{array}{l}\text { Reasonable Travel } \\
\text { Cost }\end{array}$ & 0 & 1 & 15 & 45 & 39 & 0.844 & 3 \\
\hline $\begin{array}{l}\text { Available Parking at } \\
\text { Mahallah }\end{array}$ & 0 & 9 & 24 & 34 & 33 & 0.782 & 4 \\
\hline More Time-Saving & 0 & 11 & 21 & 38 & 30 & 0.774 & 5 \\
\hline $\begin{array}{l}\text { Poor Service of } \\
\text { Public } \\
\text { Transportation }\end{array}$ & 0 & 7 & 27 & 41 & 25 & 0.768 & 6 \\
\hline $\begin{array}{l}\text { Safe to Travel by } \\
\text { Car }\end{array}$ & 4 & 12 & 36 & 26 & 22 & 0.700 & 7 \\
\hline $\begin{array}{l}\text { Available Parking at } \\
\text { Kulliyyah }\end{array}$ & 14 & 26 & 36 & 20 & 4 & 0.548 & 8 \\
\hline $\begin{array}{l}\text { Safe to Park Car in } \\
\text { Kulliyyah }\end{array}$ & 24 & 30 & 24 & 21 & 1 & 0.490 & 9 \\
\hline $\begin{array}{l}\text { Safe to Park Car in } \\
\text { Mahallah }\end{array}$ & 22 & 33 & 28 & 14 & 3 & 0.486 & 10 \\
\hline
\end{tabular}

Source: Primary Calculation, 2012

*(5) Extremely Agreeable, (4) Very Agreeable, (3) Fairly Agreeable, (2) Not Very Agreeable, (1) Extremely Not Agreeable

**R.I.I= Relative Importance Index

\section{Willingness to shift from motorcars to sustainable travel modes}

The results showed that $86 \%$ of the total respondents were willing to change travel mode choice from motorcars to other travel modes which are more sustainable. Only $14 \%$ of the respondents were not willing to change travel mode from motorcars to other travel modes. The measures which could be considered for the change in the travel mode choice, among those who were willing to change travel mode, was also analysed. The reasons for not willing to change travel mode choice is also included in this section.

The application of measures for a change in travel modes other than motorcars were analysed by ranking the preferences of the respondents using Relative Importance Index method. Table 4 shows the preferences of the 
respondents on the measures to induce a shift from using motorcars to other sustainable travel modes.

Table 4 Preferences of the Respondents on the Measures to Shift from Motorcars to Sustainable Travel Modes $(n=86)$

\begin{tabular}{|l|c|c|c|c|c|c|c|}
\hline \multirow{2}{*}{ Statement of Measures } & \multicolumn{5}{|c|}{ Frequency of Respondents } & \multirow{2}{*}{ RII** } & \multirow{2}{*}{ Rank } \\
\cline { 2 - 8 } & $\mathbf{( 1 )}$ & $\mathbf{( 2 )}$ & $\mathbf{( 3 )}$ & $\mathbf{( 4 )}$ & $\mathbf{( 5 )}$ & & \\
\hline Upgraded bus service & 5 & 7 & 7 & 11 & 7 & 0.595 & 1 \\
\hline $\begin{array}{l}\text { Improved pedestrian walkway } \\
\text { and bicycle path }\end{array}$ & 15 & 9 & 1 & 7 & 4 & 0.549 & 2 \\
\hline Limited parking space & 3 & 9 & 17 & 15 & 5 & 0.513 & 3 \\
\hline Incentives by the University & 10 & 7 & 15 & 11 & 13 & 0.490 & 4 \\
\hline Strict traffic regulations & 6 & 12 & 10 & 12 & 18 & 0.488 & 5 \\
\hline
\end{tabular}

Source: Primary Calculation, 2012

*(5) Extremely Preferable, (4) Very Preferable, (3) Fairly Preferable, (2) Not Very Preferable, (1) Extremely Not Preferable

The respondents had expressed that "upgrading existing bus services" was the most important and preferred measures that should be taken to allow a shift from using motorcars to other travel modes. This is followed by "improvement in the pedestrian walkway and bicycle path", "limiting the number of existing parking spaces", "incentives by the University" for using sustainable transportation modes and finally implementing "strict traffic regulations" to control the use of motorcars on-campus.

The deterrent factors for not willing to make mode choice shift from motorcars to other sustainable travel modes, as expressed by the respondents, is given in table 5. The results showed that the "clear advantages of using motorcars" was the most important deterrents for not willing to make a shift from motorcars to other sustainable travel modes. This is followed by "lack of initiatives by the authorities" to allow a shift to other travel modes, "poor public transportation services", "preference to drive alone with comfort and privacy" and "poor facilities for walking or bicycling" on-campus.

Table 5 Deterrents for not willing to Shift from Motorcars to other Sustainable Travel Modes ( $n=14)$

\begin{tabular}{|c|c|c|c|c|c|c|c|}
\hline \multirow{2}{*}{$\begin{array}{l}\text { Statements of } \\
\text { Deterrents }\end{array}$} & \multicolumn{5}{|c|}{ Frequency of Respondents } & \multirow{2}{*}{$\mathbf{R I I}{ }^{* *}$} & \multirow{2}{*}{ Rank } \\
\hline & $(1)^{*}$ & $(2)^{*}$ & $(3)^{*}$ & $(4) *$ & $(5)^{*}$ & & \\
\hline $\begin{array}{l}\text { Prefer advantage of } \\
\text { using motorcars }\end{array}$ & 0 & 0 & 0 & 3 & 11 & 0.957 & 1 \\
\hline $\begin{array}{l}\text { Not used to using } \\
\text { other travel modes }\end{array}$ & 0 & 0 & 0 & 6 & 8 & 0.914 & 2 \\
\hline $\begin{array}{l}\text { Absence of } \\
\text { motivation from } \\
\text { university }\end{array}$ & 0 & 0 & 0 & 7 & 7 & 0.900 & 3 \\
\hline
\end{tabular}


Nelza Lynna Abdul Rahim \& Abdul Azeez Kadar Hamsa

Analysis of Factors Influencing Use of Motorcars in International Islamic University Malaysia

\begin{tabular}{|l|c|c|c|c|c|c|c|}
\hline $\begin{array}{l}\text { Poor service of public } \\
\text { transportation }\end{array}$ & 0 & 0 & 0 & 9 & 5 & 0.871 & 4 \\
\hline Prefer to drive alone & 2 & 2 & 1 & 5 & 4 & 0.700 & 5 \\
\hline $\begin{array}{l}\text { Uneven topography } \\
\text { for walking and } \\
\text { cycling }\end{array}$ & 0 & 2 & 7 & 4 & 1 & 0.657 & 6 \\
\hline $\begin{array}{l}\text { Plenty parking in } \\
\text { campus }\end{array}$ & 0 & 4 & 6 & 3 & 1 & 0.614 & 7 \\
\hline $\begin{array}{l}\text { Poor facilities for } \\
\text { walking and cycling }\end{array}$ & 0 & 5 & 7 & 2 & 0 & 0.557 & 8 \\
\hline $\begin{array}{l}\text { Having disability or } \\
\text { illness }\end{array}$ & 12 & 0 & 0 & 0 & 2 & 0.314 & 9 \\
\hline
\end{tabular}

Source: Primary Survey, 2012 *(5) Most Likely, (4) Least Likely, (3) Likely, (2) Less Likely, (1) Least Likely $* *$ R.I.I= Relative Importance Index

\section{Differences in the level of agreement on factors influencing use of motorcars between regular and occasional users}

Only "time-saving" factor was found statistically significant, $(\mathrm{t}$-test value $=$ $10.275 ; \mathrm{p}=0.000$ ) among the factors influencing use of motorcars between regular and occasional users. The other factors were not significant statistically among the factors influencing use of motorcars between regular and occasional users. Due to limitation of space, table 6 shows t-test and significance value of only four factors.

It can be concluded that the significant factor which contributes to the use of motorcars to the Kulliyyah from Mahallah is greatly influenced by the "time-saving" factor. The mean values between groups on the "time-saving" factor, where group of respondents who use car regularly has higher means of 4.43 compared to group of respondents who use car occasionally with lower means of 3.00. Furthermore, when comparing mean value of other factors, the regular users of motorcars were normally had higher preferences on the factors such as "safety of trip makers, "available parking at Mahallah" and "safety of cars parked at the Kulliyyah" which prompted them to use motorcars oncampus regularly.

Table 6 T-Test on the Factors Influencing Use of Motorcars to Kulliyah between Regular and Occasional Users

\begin{tabular}{|l|c|c|c|c|c|c|c|c|}
\hline \multirow{2}{*}{ Parameters } & \multicolumn{2}{|c|}{ Time-Saving } & \multicolumn{2}{|c|}{$\begin{array}{c}\text { Safety of Trip } \\
\text { Maker }\end{array}$} & \multicolumn{2}{c|}{$\begin{array}{c}\text { Available } \\
\text { Parking at } \\
\text { Mahallah }\end{array}$} & \multicolumn{2}{|c|}{$\begin{array}{c}\text { Safety of Car } \\
\text { Parked at } \\
\text { Kulliyyah }\end{array}$} \\
\cline { 2 - 8 } & Mean & $\begin{array}{c}\text { Std. } \\
\text { Devia } \\
\text { tion }\end{array}$ & Mean & $\begin{array}{c}\text { Std. } \\
\text { Deviati } \\
\text { on }\end{array}$ & Mean & $\begin{array}{c}\text { Std. } \\
\text { Devia } \\
\text { tion }\end{array}$ & Mean & $\begin{array}{c}\text { Std. } \\
\text { Deviati } \\
\text { on }\end{array}$ \\
\hline $\begin{array}{l}\text { Regular } \\
\text { User (n=69) }\end{array}$ & 4.43 & 0.590 & 3.57 & 1.040 & 4.02 & 1.008 & 3.49 & 1.120 \\
\hline
\end{tabular}


PLANNING MALAYSIA:

Journal of the Malaysia Institute of Planners (2013)

\begin{tabular}{|c|c|c|c|c|c|c|c|c|}
\hline $\begin{array}{l}\text { Occasional } \\
\text { User }(n=31)\end{array}$ & 3.00 & 0.795 & 3.38 & 1.161 & 3.74 & 0.880 & 3.38 & 1.206 \\
\hline $\begin{array}{l}t \text {-Test } \\
\text { Statistics }\end{array}$ & \multicolumn{2}{|c|}{$\begin{array}{l}t(98)=10.275 \\
p=0.000\end{array}$} & \multicolumn{2}{|c|}{$\begin{array}{l}t(98)=0.847 \\
p=0.399\end{array}$} & \multicolumn{2}{|c|}{$\begin{array}{l}t(98)=1.385 \\
p=0.169\end{array}$} & \multicolumn{2}{|c|}{$\begin{array}{l}t(98)=0.453 \\
p=0.651\end{array}$} \\
\hline
\end{tabular}

\section{RECOMMENDATIONS AND CONCLUSIONS}

In this research, the analysis of Pearson Chi-Square, Pearson Correlation Coefficient and T-Test were applied to determine the significant factors influencing use of motorcars on-campus among students. The significant factors influencing use of motorcars on-campus among students include:

- Year of study

$1^{\text {st }}$ and $2^{\text {nd }}$ year students were found more likely to use motorcars than $3^{\text {rd }}$ year and higher year students

- Vehicle registration status

Those students without vehicle stickers, indicating illegal use of motorcars in campus, were more likely to use motorcars on-campus than students having vehicle stickers.

- Travel time by walking from Mahallah to Kulliyyah

A significant positive correlation between travel time by walking and use of motorcars was noted. Students with higher travel time by walking from Mahallah to Kulliyyah were more likely to use motorcars to the Kulliyyah.

- Experienced delay time to Kulliyyah

A significant negative correlation was found between delay time and use of motorcars to Kulliyyah. It showed that lesser the delay time to Kulliyyah, the higher the dependency on the use of motorcars to Kulliyyah and vice versa.

This research also highlights that the travel time by motorcars was a significant factor that differentiates preference in using motorcars to Kulliyyah between regular and occasional users. It means that the frequency of using motorcars to Kulliyyah either regularly or occasionally depends on how students perceive the amount of time involved when making a trip by motorcars from Mahallah to Kulliyyah.

This research also highlights that there is an opportunity, as expressed by the respondents, for shifting from motorcars to sustainable travel modes. Only $16 \%$ of the respondents were not willing to shift from motorcars to other 
Nelza Lynna Abdul Rahim \& Abdul Azeez Kadar Hamsa

Analysis of Factors Influencing Use of Motorcars in International Islamic University Malaysia

sustainable travel modes. The reasons being due to the theory of utility maximisation where they prefer greater benefits from their trips, for example travel time, the fare, the level of comfort and ease of accessibility offered by motorcars (DzikanKottenhoff and Lindström Olsson, 2003). The other reasons cited include: not familiar to use other travel modes and absence of motivational initatives by the authority concerned to indulge in the mode shift. On the other hand, $86 \%$ of the respondents were willing to indulge in the mode shift from motorcars to other sustainable travel modes, if measures such as upgrading bus services on-campus and improving facilities and infrastructure for walking and cycling are implemented.

\section{REFERENCES}

Adèr, H.J. (2008). Chapter 14: Phases and initial steps in data analysis. In H.J. Adèr \& G.J. Mellenbergh (Eds.) (with contributions by D.J. Hand), Advising on Research Methods: A consultant's companion (pp. 333-356). Huizen, the Netherlands: Johannes van Kessel Publishing.

Algers, S. Hugosson, B \&Lindqvist Dillén,J. (1995). Swedish value of time study in 1994.Transek, Stockholm.

Ben-Akiva, Walker, M., Bernardino, J., Gopinath, A.T., Morikawa, T. and Polydoropoulou (1999). An Integration of Choice and Latent Variable Models, In Mahmassani, H. (ed.) Perpetual Motion: Travel Behavior Research Opportunities and Application Challenges.

Colburn, A. (2003). The Lingo of Learning: 88 Education Terms every Science Teacher Should Know. United States: National Science Teachers Association Press.

Downs, A. (2004). Still Stuck in Traffic. Brookings Institution Press, Washington, D.C.

Dzikan, K. \& Olsson, L. (2003).Factors that Influence Choice of Travel Mode in Major Urban Area.Department of Infrastructure and Planning and division of Transportation and Logistics at the Royal Institute of Technology.ISSN 1651-0216.

Farah Diyanah Ismail, Abdul Azeez Kadar Hamsa and Mansor Ibrahim (2012). Analysis of Factors Influencing the Stated Preference of Academic Employees towards Telecommuting in IIUM Campus, Gombak, Planning Malaysia - Journal of the Malaysian Institute of Planners, Vol. 10. pp. 4166.

Forward, S. E. (1998b). Modes of Transport On Short Journeys: Attitudes and Behaviour of the Inhabitants of Gothenburg. Report 437, Swedish Road and Transport Research institute, Linköping; Sweden. 
Gilbert, R. \& Tanguay, H. (2000).Brief Review of Some Relevant Worldwide Activity and Development of an Initial Long List of Indicators. Sustainable Transportation Performance Indicators (STPI) Project, Center for Sustainable Transportation (CST), Toronto.

Goodwin, P. (1998). The End of Equilibrium, In Garling, T., Laitila, T. and Westin, K. (eds.) Theoretical Foundation of Travel Choice Modeling, Elsevier Science Ltd. UK.

Goodwin, P. Hallett, S. Kenny, F. and Stokes, G. (1991).Transport: The new realism. TransportStudies Unit, University of Oxford, UK.

Grue, B. \& Hoelsaeter, A. (2000).Park-and-Ride and Bike-and-Ride: Factors that Influence the Access Mode Choice to Railway Stations in the Oslo Area. Report \# TOI-1159, Oslo, Norway.

Hjorthol, R. J. (1999).Women'sand Men'sPerceptionof TransportProperties AndSymbolic Value. SociologiskTidskrift, Vol. 7 No. 2.

Hydén, C. \& Nilsson, A. \&Risser, R. (1998). WALCYNG - How to enhance WALking and CYcliNG instead of shorter car trips and to make these modes safer. Final Report.Department of Traffic Planning and Engineering, University of Lund, Sweden.

Ingram, K.G. and Z. Liu.(1999). Determinants of Motorization and Road Provision.The World Bank, Washington D.C.

Jensen, M. (1997) The Need to Drive a Car, paper for The Oslo Research Conference: Society, Environment, and Sustainability.

Kottenhoff, K. (1999). Evaluation of Passenger Train Concepts. Methods and Results Of Measuring Travellers Preferences in Relation To Costs. KTH TRITA-IP FR 99-58. Stockholm.

Laerd Statistics. www.laerdstatistics.com.

Loncar-Lucassi, $\quad$ V. $\quad$ M. (1998). Railvs.bus?Softfactors ontravelertransportationchoices.KFB-Meddelande 1998:1, Stockholm.

Louviere, J., D. Hensher and J. Swait (2000), Stated Choice Methods: Analysis and Applications, Cambridge University Press, New York.

Meead Saberi Kalaee, Mohammad Reza Rezaeian, Mohammad Reza Ahadi, \& Gholam Ali Shafabakhsh.(2009). Evaluating the Factors Affecting Student Travel Mode Choice. Retrieved from www.trforum.org/forum/.../2009_21_TravelModeChoice_paper.pdf.

MugoFridah W. (2002).Sampling in Research.Retrieved from: http://www.indiana.edu/ educy520/sec5982/week_2/mugo02sampling.pdf.

Norsyuhadah Norzalwi \& Amiruddin Ismail. (2011). Public Approach Towards Sustainable Transportation in UKM's Campus. Australian Journal of Basic and Applied Sciences, 5(5): 1332-1337. 
Nelza Lynna Abdul Rahim \& Abdul Azeez Kadar Hamsa

Analysis of Factors Influencing Use of Motorcars in International Islamic University Malaysia

RAC.(1994). Car Dependence.ESRC Transport Studies Unit. UK: University of Oxford.

Schaefer, K. and Sclar, E. (1980).Access for All: Transportation and Urban Growth. Columbia University Press, NewYork.

University of Bradford. (2004).SMART MOVE Travel Plan 2004-2009. Retrieved

from:

http://www.brad.ac.uk/admin/ecoversity/travel/TravelPlan.pdf.Retrieved on April, 5, 2012.

Webster, M. (1985).Webster'SNith New Collegiate Dictionary.Meriam Webster Inc.

Yamane, Taro. (1967). Statistics, An Introductory Analysis. $2^{\text {nd }}$ Ed. NY: Harper and Row. 